\title{
First record of the invasive tapeworm, Schyzocotyle acheilognathi (Pseudophyllidea; Bothriocephalidae) in native freshwater fish, Brazil
}

\author{
GEOVANE A. DE SOUZA ${ }^{1}$, VICTOR O. MORESCA ${ }^{2}$, GUSTAVO M. \\ TEIXEIRA ${ }^{2}$, FERNANDO C. JEREP ${ }^{3}$ and ALINE AGUIAR ${ }^{2}$ \\ ${ }^{1}$ Laboratório de Sistemática e Tafonomia de Vertebrados Fósseis, Departamento de Geologia \\ e Paleontologia, Museu Nacional, Universidade Federal do Rio de Janeiro, Avenida Pedro II, \\ s/n, Quinta da Boa Vista, São Cristóvão, 20940-040 Rio de Janeiro, RJ, Brazil \\ ${ }^{2}$ Laboratório de Invertebrados Aquáticos e Simbiontes, Departamento de Biologia Animal e Vegetal, Centro de Ciências \\ Biológicas, Universidade Estadual de Londrina, Rodovia Celso Garcia Cid, PR 445, Km 380, s/n, 86057-970 Londrina, PR, Brazil \\ ${ }^{3}$ Museu de Zoologia, Departamento de Biologia Animal e Vegetal, Centro de Ciências Biológicas, Universidade \\ Estadual de Londrina, Rodovia Celso Garcia Cid, PR 445, Km 380, s/n, 86057-970 Londrina, PR, Brazil \\ Manuscript received on October 10, 2017; accepted for publication on January 19, 2018

\begin{abstract}
Schyzocotyle acheilognathi is a tapeworm cestode commonly found in native freshwater fishes from Asia. This cestode has low host specificity and for that reason it has been registered parasitizing more than 200 cultured and wild fish species, besides amphibians, reptiles and birds from different regions of the world. With a high pathogenic potential, S. acheilognathi may cause mortalities in highly infected fish. In South America, Schyzocotyle was reported in Cyprinus carpio from a Brazilian fish farm at the municipality of Cornélio Procópio, northern Paraná State and from the natural environment in C. carpio from Neuquen River, Patagonia, Argentina. So far, there has been no report of this parasite in South American native fishes. Herein we report the first occurrence of the invasive tapeworm S. acheilognathi in Rineloricaria pentamaculata (Siluriformes, Loricariidae), a native armored freshwater catfish from southern Brazil.
\end{abstract}

Key words: Cestoda, Bothricephalus, fish farm, helminthes, introduced species, parasite invasion.

\section{INTRODUCTION}

Invasive species is a major cause of biological diversity loss (Baillie et al. 2004). The fish escape from fish farms is crucial on the dispersion of exotic species worldwide in aquatic environments (Agostinho et al. 2006). This escape is often associated to the diffusion of new pathogens carried by them (Agostinho et al. 2006).

Correspondence to: Geovane Alves de Souza

E-mail: geoosoouza@gmail.com

\section{INVASIVE TAPEWORM}

The tapeworm Schyzocotyle acheilognathi (Yamaguti, 1934) Brabec, Waeschenbach, Scholz, Littlewood and Kuchta, 2015 (syn. Bothriocephalus acheilognathi Yamaguti, 1934) is a cestode commonly found in native freshwater fishes from Asia. This cestode has low host specificity (Salgado-Maldonado et al. 2015) and for that reason it has been registered parasitizing more than 200 cultured and wild fish species, besides amphibians, 
reptiles and birds from different regions of the world (Scholz et al. 2012, Yera et al. 2013). In fishes, the tapeworm life cycle starts with the host being infected by ingestion of copepod crustaceans (Cyclopoida) contaminated with coracid larvae (Liao and Shih 1956).

Exotic in the Neotropical region, $S$. acheilognathi occurrence has been substantially related to carp fish farming, usually from places with high occurrence of this parasite (Salgado-Maldonado and Pineda-López 2003, Salgado-Maldonado et al. 2015). Eventually, the parasite reaches the natural environment and its ichthyofauna through contaminated fish-farming escapes, causing serious injuries to native fishes such as perforation of the gastrointestinal tract, anemia, reduction of growth and reproduction capacity, muscle fatigue, weakened swimming capacity and secondary bacterial infections. With a high pathogenic potential, S. acheilognathi may cause mortalities in highly infected fish (SalgadoMaldonado and Pineda-López 2003).

This cestode is widely distributed throughout the Americas. In North America, many authors recorded $S$. acheilognathi in several localities in the United States (Cole and Choudhury 2016). Salgado-Maldonado and Rubio-Godoy (2014) updated the distribution of this tapeworm in Mexico, where the species peaks its invasive host record in America (50 freshwater fish species from seven families). In Central America, this parasite has been recorded from Puerto Rico (Bunkley-Williams and Williams 1994), Panama (Choudhury et al. 2013) and Honduras (Salgado-Maldonado et al. 2015). In South America, Schyzocotyle was reported in Cyprinus carpio Linnaeus, 1758 from a Brazilian fish farm at the municipality of Cornélio Procópio, northern Paraná State (Rego et al. 1999), and inhabiting natural environment in C. carpio from Neuquen River, Patagonia, Argentina (Waicheim et al. 2014). So far, there was no report of this parasite in South American native fishes. Herein we firstly report the invasive tapeworm S. acheilognathi in Rineloricaria pentamaculata Langeani and de Araújo, 1994 (Siluriformes, Loricariidae), a native armored freshwater catfish from southern Brazil.

Fishes were collected monthly in Lajeadão River (Figure 1d), tributary of Ivaí River, located in municipality of Borrazópolis, Northern Paraná State, Brazil (2401'32.85's; 5136'46.98”'W). Collection permit was granted by Sisbio to FCJ (\#42829-1) and Ethical Use of Animals Commission of Universidade Estadual de Londrina (CEUA/UEL 11110.2015.14). Fish specimens were captured with sieves ( $85 \mathrm{~cm}$ diameter / $0.2 \mathrm{~mm}$ mesh) and a Kicknet that consists of a net ( $2 \mathrm{~mm}$ mesh) with two wooden rods on the edges. Hosts were euthanized with Eugenol overdosage $3.000 \mathrm{mg} / \mathrm{L}$ (Lucena et al. 2013); mass and length were taken before necropsy. Vouchers were cataloged and deposited at the Museu de Zoologia da Universidade Estadual de Londrina. Fish intestine was placed on petri dish and analyzed under stereomicroscopy for parasites. Collected cestode was fixed with slight compression between lamina and glass slide using AFA, stained with cloridric carmine, dehydrated in alcoholic series, and diaphanizad with Eugenol in temporary mounts (Eiras et al. 2006). Furthermore, we used taxonomic descriptions and others reports, such as Yamaguti (1934), Pool (1987) and Scholz (1997) to identification. The specimen was deposited in the Coleção Helmintológica do Instituto Oswaldo Cruz (CHIOC), Rio de Janeiro, under accession number CHIOC 38570.

Fifteen specimens of $R$. pentamaculata were collected, and only a single specimen presented one cestode parasitizing the small intestine. The cestode was identified as $S$. acheilognathi by the following combination of characters (in micrometers): body length (about 2550 long); a wide scolex heartshaped (581.3 long x 723.4 width) with narrow, deep dorsally and lateral bothrias short and very deep; neck absent and first proglottid imediatelly posterior to scolex; imature proglottids much narrower 


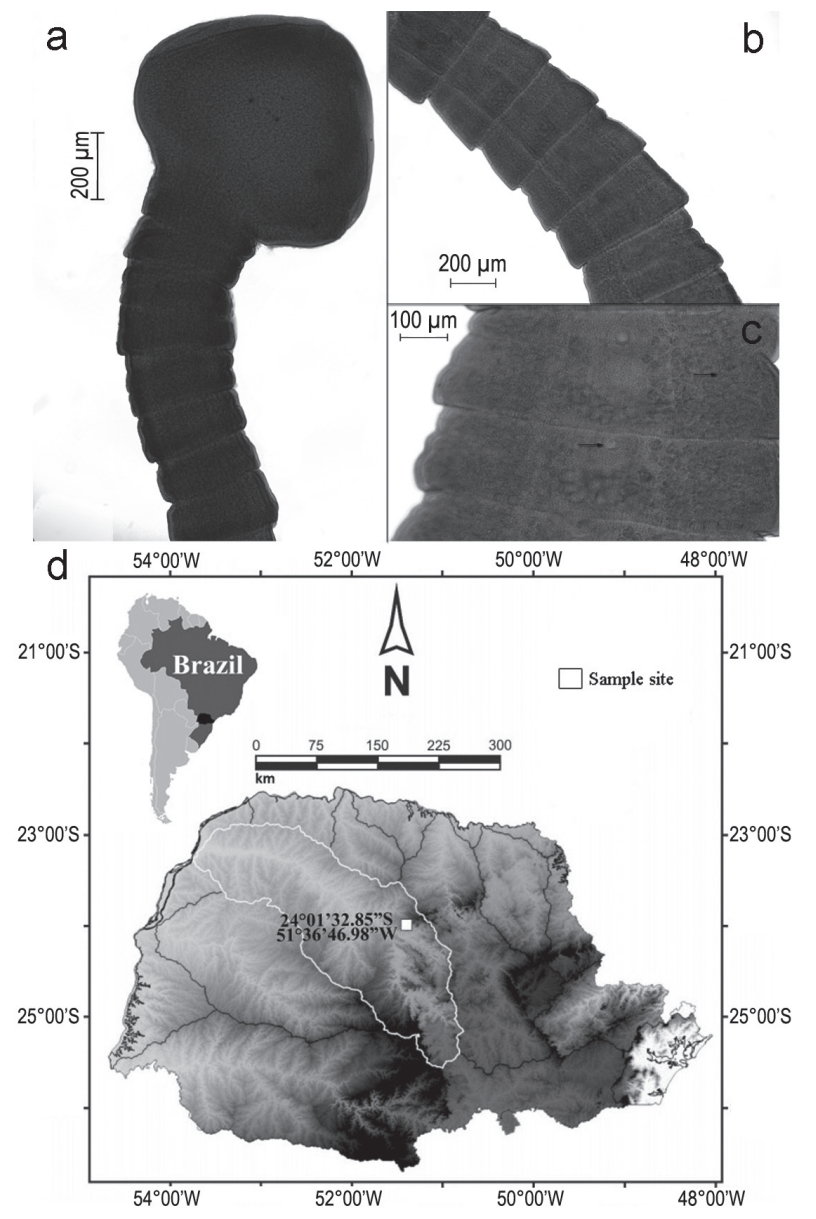

Figure 1 - Schyzocotyle acheilognathi from the fish Rhineloricaria pentamaculata. a. Anterior portion. b. Mature proglottids from medial portion. c. Mature proglottids showing genital pore. d. Sampling site of the present study (Lajeadão River, tributary of Ivaí River, municipality of Borrazópolis, Northern Paraná State, Brazil).

than scolex (196.7 long x 203.97 width); mature proglottids 224.2 long and 534.1 width, gravid proglottids 316.7 long and 769.5 width; imature, mature and gravid segments with rounded edges; cirrus sac 77 long and 70 width; medullary testes; lobed ovary 365.5 long and 179 width near posterior margin of proglottids; eggs $47-59$ long and $31-37$ width (10 eggs measured) (Figure 1a-c).

Rinelocaria pentamaculata lives in a widely variety of habitats, from streams to great lakes (Langeani and Araújo 1994, Reis and Cardoso
2001). As a bottom dweller fish, it is mostly found among foliage or on muddy or sandy bottom (FCJ, personal observation), feeding on small organisms on the substrate (Rapp Py-Daniel 1997). This habit must have facilitated the ingestion of infected cyclopoid and consequently S. acheilognathi. The stretch of stream where $R$. pentamaculata were collected is under strong anthropic influence and presents agriculture along its banks and a narrow band of riparian vegetation. Likely, S. acheilognathi could have been introduced into this stream by parasitized carps that accidentally have escaped from fish farm near to sampled site.

Schyzocotyle acheilognathi presents high capacity of adaptation to several environments (Pérez-Ponce de León et al. 2009). Due to wide distribution around the world mostly achieved by invasion of new habitats, this cestode is considered to be the most successful known freshwater helminth (Dove and Fletcher 2000), being recorded in several fish species and other vertebrate groups due to its great rate of adaptation to phylogenetically distant hosts. According Salgado-Maldonado and Pineda-López (2003), the high adaptive capacity of this cestode in Mexico is related to a combination of factors: its low intermediate and definite hosts specificity; the high abundance of cyclopoid copepods in Mexican freshwater habitats (which are intermediate host of this helminth); the amount of open niche availability, the existence of several dispersion windows throughout the year; the stable appropriate temperature for larval development all year round $\left(16-25^{\circ} \mathrm{C}\right)$; the presence of birds as eggs carriers; and the accentuated anthropogenic introduction of carps which are usual hosts to $S$. acheilognathi. Alarmingly, the same conditions are commonly observed in freshwater habitat throughout Brazil, therefore must be considered a country with elevated potential for fast diffusion of S. acheilognathi.

The presence of this parasite in a Brazilian native freshwater fish is a new record of introduction 
of exotic species, marking the importance of parasite fauna investigation and inventory, as well as the study of introduced fishes in natural environments. Besides predation and competition for resources, non-native fishes directly affect habitat integrity by dissemination of exotic parasite species that accidentally infect native species, culminating in irreversible reduction of local diversity. The introduction of exotic organism and habitat destruction are among the main threats to conservation of endemic and extinction-susceptible species (Agostinho et al. 2005).

\section{ACKNOWLEDGMENTS}

We would like to thank Universidade Estadual de Londrina and Conselho Nacional de Desenvolvimento Científico e Tecnológico (CNPq) by financial support and to our lab colleagues for help in fieldwork.

\section{REFERENCES}

AGOSTINHO AA, PELICICE FM AND JÚLIO JR HF. 2006. Biodiversidade e introdução de espécies de peixes: unidades de conservação. Unidades de Conservação: ações para valorização da biodiversidade. In: Campos JB, Tossulino MGP and Muller CRC (Eds), Curitiba: Instituto Ambiental da Paraná, p. 95-117.

AGOSTINHO AA, THOMAZ SM AND GOMES LC. 2005. Conservação da biodiversidade em águas continentais do Brasil. Megadiversidade 1: 70-78.

BAILLIE JEM ET AL. 2004. 2004 IUCN Red List of Threatened Species: A Global Species Assessment. In: Baillie JEM, Hilton-Taylor C and Stuart SN (Eds), IUCN, Switzerland and Cambridge, UK, $191 \mathrm{p}$.

BRABEC J, WAESCHENBACH A, SCHOLZ T, LITTLEWOOD DTJ AND KUCHTA R. 2015. Molecular phylogeny of the Bothriocephalidea (Cestoda): molecular data challenge morphological classification. Int J Parasitol 45: 761-771.

BUNKLEY-WILLIAMS L AND WILLIAMS EH. 1994. Parasites of Puerto Rican freshwater sport fishes. Department of Natural and Environmental Resources and Department of Marine Sciences: University of Puerto Rico, 164 p.

CHOUDHURY A, ZHENG S, DE LEÓN GPP, MARTÍNEZAQUINO A, BROSSEAU C AND GALE E. 2013. The invasive Asian fish tapeworm, Bothriocephalus acheilognathi Yamaguti, 1934, in the Chagres River/Panama Canal drainage, Panama. BioInvasions Rec 2: 99-104.

COLE RA AND CHOUDHURY R. 2016. Invasive species compendium: Bothriocephalus acheilognathi. Available at: http://www.cabi.org/isc/datasheet/91669.

DOVE ADM AND FLETCHER AS. 2000. The distribution of the introduced tapeworm Bothriocephalus acheilognathi in Australian freshwater fishes. J Helminthol 74: 121-127.

EIRAS JC, TAKEMOTO RM AND PAVANELLI GC. 2006. Métodos de estudo e técnicas laboratoriais em parasitologia de peixes, $2^{\text {nd }}$ ed., Maringá: Eduem, $171 \mathrm{p}$.

LANGEANI F AND ARAÚJO RB. 1994. O gênero Rineloricaria Bleeker, 1862 (Ostariophysi, Siluriformes) na bacia do rio Paraná superior: Rineloricaria pentamaculata sp. n. e Rineloricaria latirostris (Boulenger, 1900). Comun Mus Cienc Tecnol Pucrs Ser Zool 7: 151-166.

LIAO H AND SHIH L. 1956. Contribution to the biology and control of Bothriocephalus gowkongensis Yeh, a tapeworm parasitic in young grasscarp (Ctenopharyngodon idellus $\mathrm{C}$. and V.). Acta Hydrobiol Sin 2: 129-185.

LUCENA CAS, CALEGARI BB, PEREIRA EHL AND DALLEGRAVE E. 2013. O uso de óleo de cravo na eutanásia de peixes. Bol Soc Bras Ictiol 105: 20-24.

PÉREZ-PONCE DE LEÓN G, ROSAS-VALDEZ R, MENDOZA-GARFIAS B, AGUILAR-AGUILAR R, FALCÓN-ORDAZ J, GARRIDO-OLVERA L AND PÉREZ-RODRÍGUEZ R. 2009. Survey of endohelminth parasites of freshwater fishes in the upper Mezquital River basin, Durango state, Mexico. Zootaxa 2164: 1-20.

POOL DW. 1987. A note on the synonomy of Bothriocephalus acheilognathi Yamaguti, 1934, B. aegyptiacus Ryšavý and Moravec, 1975 and B. kivuensis Baer and Fain, 1958. J Parasitol Res 73: 146-150.

RAPP PY-DANIEL LH. 1997. Phylogeny of the neotropical armored catfishes of the subfamily Loricariinae (Siluriformes; Loricariidae). PhD Thesis, University of Arizona, $284 \mathrm{p}$.

REGO AA, CHUBB JC AND PAVANELLI GC. 1999. Cestodes in South American freshwater teleost fishes: keys to genera and brief description of species. Rev Bras Zool 16: 299-367.

REIS RE AND CARDOSO AR. 2001. Two new species of Rhineloricaria from southern Santa Catarina and northern Rio Grande do Sul, Brazil (Teleostei: Loricariidae). Ichthyol Explor Freshw 12: 319-332.

SALGADO-MALDONADO G, MATAMOROS WA, KREISER BR, CASPETA-MANDUJANO JM AND MENDOZA-FRANCO EF. 2015. First record of the invasive Asian fish tapeworm Bothriocephalus acheilognathi in Honduras, Central America. Parasite 22: 5. SALGADO-MALDONADO G AND PINEDA-LÓPEZ RF. 2003. The Asian fish tapeworm Bothriocephalus 
acheilognathi: a potential threat to native freshwater fish species in Mexico. Biol Invasions 5: 261-268.

SALGADO-MALDONADO G AND RUBIO-GODOY M. 2014. Helmintos parásitos de peces de agua dulce introducidos. Especies acuáticas invasoras en México. In: Mendoza R and Koleff P (Eds), Comisión Nacional para el Conocimiento y Uso de la Biodiversidad, MX, p. 269-285.

SCHOLZ T. 1997. A revision of the species of Bothriocephalus Rudolphi, 1808 (Cestoda: Pseudophyllidea) parasitic in American freshwater fishes. Syst Parasitol 36: 85-107.

SCHOLZ T, KUCHTA R AND WILLIAMS C. 2012. Bothriocephalus acheilognathi. In: Woo PT and Buchmann
K (Eds), Fish Parasites: pathobiology and protection, Wallingford: CAB International, UK, p. 282-297.

WAICHEIM A, BLASETTI G, CORDERO P, RAUQUE C AND VIOZZI G. 2014. Macroparasites of the invasive fish, Cyprinus carpio, in Patagonia, Argentina. Comp Parasitol 81: 270-275.

YAMAGUTI S. 1934. Studies on the helminth fauna of Japan. Part 4. Cestodes of fishes. Jp J Zool 6: 1-112.

YERA H, KUCHTA R, BRABEC J, PEYRON F AND DUPOUY-CAMET J. 2013. First identification of eggs of the Asian fish tapeworm Bothriocephalus acheilognathi (Cestoda: Bothriocephalidea) in human stool. Parasitol Int 62: 268-271. 